\title{
Viral Gene
}

National Cancer Institute

\section{Source}

National Cancer Institute. Viral Gene. NCI Thesaurus. Code C16620.

Genes of viral origin. 